\title{
Passo a Dois: percepção tátil-cinética na mobilidade com cão-guia
}

\author{
Olivia von der Weid ${ }^{1}$
}

\section{Resumo}

${ }^{1}$ Universidade Federal Fluminense, Niterói, Rio de Janeiro, Brasil

Este artigo é um desdobramento das reflexões apresentadas na mesa redonda “Movimentos, percepções e práticas" durante a VII Reunião de Antropologia da Ciência e da Tecnologia. Apresento como venho articulando os três temas que deram o título à mesa, tomando como base a pesquisa que desenvolvo desde o doutorado sobre as percepções de mundo de pessoas cegas. Em um segundo momento, faço uma aproximação mais etnográfica à temática a partir das investigações de campo que, desde 2016, venho realizando no Centro de Formação de Treinadores e Instrutores de Cães-guia do Instituto Federal Catarinense (IFC-Camboriú). Finalizo o artigo com considerações sobre os desafios que a investigação da experiência de mundo de pessoas cegas coloca ao método e à escrita etnográfica.

Palavras-chave: Percepção. Cegueira. Técnica. Movimento. Dança.

\section{Pas de Deux: tactile-kinetic perception in mobility with a guide dog}

\begin{abstract}
This article is an unfolding of the reflections presented in the round table "Movements, perceptions and practices", during the VII Meeting of Anthropology of Science and Technology. I present how I've been articulating the three themes that gave the title to the table based on the research that I have developed since my doctorate on the perceptions of the world of blind people. In a second step, I make a more ethnographic approach to the theme based on field investigations that, since 2016, I have been carrying out at the Training Center for Trainers and Instructors of Guide Dogs of the Instituto Federal Catarinense (IFC-Camboriú, South Brazil). I end the article with considerations about the challenges that the investigation of the world experience of blind people poses to ethnographic method and writing.
\end{abstract}

Keywords: Perception. Blindness. Technique. Movement. Dance. 


\section{Introdução}

$\mathrm{H}^{2}$

á uma tensão criativa que o campo de estudos sobre deficiência traz para as análises

sociais que pode ser traduzida na pergunta: "Como falar do corpo" na deficiência? (LATOUR, 2004). Devemos pensá-lo como materialidade moldada pela linguagem e pelos códigos sociais? Ou a partir de suas propriedades materiais e orgânicas? Ou, ainda, a partir das práticas e daquilo que corpos diversos articulam e potencializam?

Nascemos e somos levados a viver de uma determinada forma. Nossa existência cotidiana corresponde a um modo de vida que corporificamos e reproduzimos. A maior parte do tempo atuamos em uma corporalidade que reflete expectativas sociais (MAUSS, 2003). Como lembra Toren (2012), a história não é externa ao que é humano, pelo contrário, tudo em nós - tanto características fisiológicas quanto aquilo que fazemos ou pensamos - manifesta o processo histórico que vivemos. Para a autora, somos produto de uma transformação contínua de um passado vivido que manifestamos e projetamos, de uma só vez, no presente. Se pararmos para pensar na palavra somático - soma - vemos que o significado de corporal é também adição: o corpo é um agregado de experiências, um agregado de vivências que, a cada nova dobra, a cada novo acontecimento vai modificando, ressoando no seu passado e no seu futuro. John Hull (2001) relata sua experiência corporificada de viver como cego após perder a visão:

No começo pensamos que a cegueira fosse algo que afetasse os olhos, depois o cérebro, depois o corpo inteiro. Começamos então a ver que a cegueira é algo que cria o seu próprio mundo. É claro, isso é também verdade para a visão. A visão também cria um mundo, mas as pessoas que enxergam não sabem disso. Afinal, as pessoas que enxergam geralmente não sabem que enxergam; elas simplesmente acham que o mundo é daquela forma. Mas o mundo não é daquela forma. Apenas o seu mundo é daquela forma, e existem muitos mundos. A existência do mundo das pessoas cegas relativiza o mundo das pessoas que enxergam. Mas, para se dar conta disso, as pessoas que enxergam precisam começar a pensar na cegueira como um mundo genuíno e independente, com as suas próprias características, suas próprias maravilhas e terrores. A cegueira afeta o corpo inteiro quando dádivas corporais subliminares, normalmente obscurecidas pela visão, começam a saltar para a superfície da consciência. Quando isso acontece, a experiência da cegueira começa a gerar um mundo. (HULL, 2001, p. 25, tradução livre)

O depoimento é bastante elucidativo de uma aproximação ontológica e sensória que venho desenvolvendo para a cegueira como um empreendimento de aprendizagem prática que vai permitindo que pessoas cegas adquiram um corpo com certas potências e 
habilidades singulares, ou seja, um modo de existência que é capaz de criar um mundo possível. Quando uma pessoa perde a visão, ou mesmo quando nasce sem o sentido visual, ela ainda não é cega, ela se torna cega por meio de um processo de aprendizagem que vai tornando o seu corpo progressivamente capaz de fazer uma série de articulações na sua relação com o ambiente, percebendo uma série de diferenças para as quais antes era insensível, pelo sobrepeso que damos à visão como sentido organizador das experiências e das relações em nossa cultura. Adquirir um corpo cego é um empreendimento que produz um meio sensorial - que Sousa (2004), por exemplo, chama de mundividência tátil - e, ao mesmo tempo, que também produz um mundo sensível.

As experiências de pessoas com deficiência iluminam o lado multinaturalista da humanidade no seio de uma cosmologia que tomou o corpo o substrato natural, independente, universal e autômato. O poder ocidental capitalista é inseparável da exclusão do corpo, do seu controle e dominação, da sua transformação em um objeto mecânico, objeto de consumo. A reforma do corpo está no coração da moral capitalista burguesa (LE BRETON, 2011). Assim como as sociedades ditas "primitivas" foram e são o outro de uma exo-antropologia (CANDEA, 2011), os anormais, como bem lembrou Foucault (2010), foram constituídos como outros da sociedade disciplinar, como pontos mesmo de sua própria organização ou deflagração.

O corpo colonizado de ontem é o corpo normativo de hoje, forjado em mecanismos de autodisciplina, autocontrole e autorregulação que interiorizamos no processo de socialização. A segunda natureza que a socialização colonial-capitalista a todos impõe - a normalidade útil e capaz - é também a mesma que oprime e exclui corpos diversos que, impossibilitados de performar a subjetividade civilizatória e seus protocolos normativos de comportamento, são muitas vezes jogados na fronteira da abjeção e da humanidade (HUGHES, 2012). A etnografia com pessoas com deficiência leva a nos confrontar com a matriz de inteligibilidade normativa - e normalizada - de nossos próprios corpos. O desafio que provocam é o de levar adiante um exercício de descolonização da corporalidade normativa assumindo o estatuto integral dos corpos diversos como corpos singulares, escapando, assim, dos binarismos - (a)normal, (in)capaz, (in)adequado. São corporalidades que nos obrigam a, no mínimo, fazer outros movimentos, outros usos de nossos corpos para estabelecer um canal de troca, uma relação comunicativa com os sujeitos de pesquisa.

Venho descrevendo as trajetórias habilidosas e criativas de pessoas cegas, a maneira como desenvolvem, em seus percursos formativos ou cotidianos, certos conhecimentos, ou formas de saber-fazer, que se originam no movimento corporal contínuo de monitoramento entre percepção e ação em diferentes ambientes. Um tipo de conhecimento que cresce em movimento, na medida em que as pessoas começam a fazer coisas. Por isso é que, quando se perde a visão, a fase do "luto" é também a fase da paralisia. É por meio da ação e do movimento que um corpo que perde a visão se torna cego, ou seja, passa a habitar uma nova condição sensorial e física que permite a criação de um mundo (REYNOLDS, 2017).

O reconhecimento de seus saberes corporificados - no caso da cegueira, o uso dos sentidos para a locomoção, para a compreensão e o controle dos objetos e do ambiente, os modos de comunicação e significação táteis, os acoplamentos humano-animais das duplas nos agenciamentos antropozootécnicos usuários e cães-guia-mostra que há um valor criativo sendo forjado que intensifica, de um lugar ainda pouco explorado pelas 
ciências humanas, a vitalidade das deficiências. É algo inteiramente novo que está se apresentando - que suplanta, transforma, aumenta, que cria novos mundos perceptivos, novas formas de conhecimento. Penso que levar a sério a experiência sensível e inventiva desses corpos em sua singularidade pode nos levar a operar uma inversão do estigma na deficiência, já que somos "nós", os "normovisuais", que precisamos aprender a habitar e a conhecer esses outros mundos. Sendo o corpo uma multiplicidade de forças e de sentidos, como incluir as razões de um corpo que não vê na observação e na descrição etnográfica?

O dispositivo metodológico da venda nos olhos para investigar a percepção e o modo de estar no mundo de pessoas cegas vem sendo utilizado por mim desde o doutorado. Tem servido como instrumento para escapar à centralidade conferida à visão tanto no método quanto nas descrições etnográficas ${ }^{1}$. Uma estratégia desenvolvida não para se aproximar da experiência inacessível do outro - a cegueira como identidade - mas para criar abertura para um espaço de observação não centrado na visualidade, em que o "não ver" é visitado como estado corporal de atenção e ontologia sensorial singular. Tomar a cegueira como "prática desejável" (DEVOS, 2018; PORCO, 2014) no trabalho de campo não significa negar a existência da exclusão social e da estigmatização, que operam apagando a diversidade corporal e mental das deficiências do espaço público. É precisamente o movimento inverso, uma forma de combater a normatização sistemática da diferença, da "singularidade impessoal" das deficiências (OVERBOE, 2012), ao considerar que a deficiência visual não é um "problema" a ser evitado ou corrigido, mas sim uma potencialidade ou um "recurso positivo" (PORCO, 2014), não apenas no que diz respeito à estética, como também às práticas de pesquisa e de produção de conhecimento.

Não temos um corpo fechado, pronto. Assim como o conhecimento de algo, ele é acréscimo. Conhecemos com todas as nossas somas, e todas as nossas vivências nos permitem conhecer algo de uma determinada maneira e não de outra. Para Kuniichi Uno (2018, p. 14), “[...] se o corpo não é um objeto ou um conjunto de órgãos, ele aparece imediatamente como questão fundamental daquilo que é a vida e a vitalidade". Como trazer para a investigação etnográfica uma sensibilidade que leve em conta a dimensão vital da corporalidade? Que desenvolve uma observação atenta a um modo mais relacional e intensivo de conhecer? O que apresento a seguir é uma experimentação nessa direção.

\section{Perceber em Movimento: conhecimento ambulatório}

Tomar o corpo como ponto de partida e fazer dele o fio condutor, eis o essencial. (NIETZSCHE, 1885, Fragmentos Póstumos 40 [15])

Na pesquisa atual, na qual acompanho as etapas de formação de cães-guia² ${ }^{2}$ realizei, por sugestão do treinador Marcos, o exercício da "caminhada vendada", experimento

Para uma discussão metodológica sobre o uso da venda como dispositivo de investigação sobre o universo perceptivo da cegueira ver von der Weid (2017).

2 A pesquisa de campo foi realizada de 2016 a 2019 no Centro de Formação de Treinadores e Instrutores de Cães-Guia do Instituto Federal Catarinense, Campus Camboriú. A etapa que dá início à formação de um cão-guia é chamada de socialização, quando o filhote, depois do desmame, fica na casa de uma família que se voluntaria para acolhêlo pelo período de 13 a 15 meses. Quando a etapa se completa, o cão retorna ao centro de formação para realizar o 
também realizado com os alunos em aprendizagem no treinamento dos cães. A proposta era ser guiada por Morena, labradora já "graduada" como guia, percorrendo um trecho de quase $2 \mathrm{~km}$, que começava no centro de treinamento e terminava no refeitório, próximo à entrada do campus.

Já havia feito caminhadas com Morena antes, ela estava passando a temporada de campo comigo. Prestar atenção em seu deslocamento de olhos abertos era uma coisa, ela sabia que estava trabalhando, pois estava sempre de colete ${ }^{3}$, mas também sabia que eu estava vendo e seu sentido de responsabilidade não era tão alto, ela farejava o ar, o chão e de vez em quando se distraía seguindo seu olfato que se interessava por algo na lateral da calçada. De minha parte, estava atenta aos seus movimentos ao longo do percurso, corrigindo quando era preciso e elogiando quando acertava. Ainda que estivesse cognitivamente concentrada no que fazia, o foco maior da minha atenção era na direção de sua cabeça, para onde olhava e se ela estava se desviando do caminho. Éramos dois seres caminhando em paralelo.

Agora, com os olhos vendados, a atenção continua alerta, não tanto pelo que a vejo fazer, mas pelo que a sinto fazer. Meus passos vão onde ela for e se não vão, se escapam para a direita, a alça do arreio tenciona e puxa para a esquerda, para a lateral do corpo onde ela está. O andar de Morena é relativamente ligeiro, posso sentir seu rebolado. A cadência e a velocidade se alteram quando me desloco com a atenção focada nas suas oscilações. Minha passada costumava se ajustar à dela, mas, no início da experiência vendada, seu andar pareceu repentino demais, como se eu não estivesse preparada para a rapidez daqueles passos, já que ainda me adaptava corporalmente à situação de andar sem ver. O cão percebe imediatamente que algo está diferente, pelo equilíbrio do corpo de quem ele está conduzindo. Os ajustes e a compreensão mútua vão se dando em movimento. Nossas sinergias vão estabelecendo o rumo de uma conversação cineticamente dinâmica, com suas próprias aberturas e fechamentos, atenuações e proeminências, velocidade e hesitação. O ritmo de nossos passos, desajustado no início, aos poucos vai se afinando.

Curiosamente, a sensação de ser guiada por Morena vitaliza em mim a memória de dançar a dois. O deslocamento inspira a memória da dança e a memória da dança inspira nosso deslocamento (TSING, 2019), fazendo com que de repente fiquem claras algumas cenas e uma série de detalhes que havia observado no processo de adaptação de duplas. Um dos grandes segredos da dança de salão é saber se deixar conduzir. Algo difícil de ser ensinado, mas que se aprende na prática. O corpo de quem é levado, independentemente do gênero de quem leva, é um corpo alerta, mas disponível, nem duro nem relaxado demais. Ainda que possa influenciar nos passos da dupla ou sugerir

treinamento, fase que dura de 4 a 6 meses, dependendo da evolução do cão. A última etapa é a adaptação do cão, já graduado como guia, com o deficiente visual que irá conduzir, essa etapa dura um mês. As três primeiras semanas são realizadas no próprio centro, período em que o deficiente visual precisa desenvolver o relacionamento adequado com o cão e a capacidade de liderá-lo, além de aprender as técnicas. A última semana da adaptação é feita no local de residência do deficiente visual, quando o instrutor marcará com a dupla os principais trajetos que irão percorrer. A partir daí, a dupla trabalhará por cerca de 8 anos quando, dependo da disposição e da saúde física e mental do cão, ele será "aposentado".

3 O colete é um artefato técnico introduzido desde os primeiros meses de vida do cão, ainda em fase de socialização, para marcar uma mudança de comportamento entre as horas livres e as que está a trabalho. Quando o cão está de colete espera-se dele um comportamento calmo, equilibrado, uma atenção focada no deslocamento e uma postura séria, o que significa que não é o momento de estimulá-lo, de afagar ou brincar com o cão, para não distrair sua atenção da atividade que está realizando. 
fluxos, ser conduzida é uma experiência de entrega, confiar ao outro o controle e a direção dos movimentos. Meu pai costumava dizer que a dança é o único lugar em que o homem manda e a mulher obedece, o homem conduz e a mulher é conduzida, mas cansei de conduzir amigas minhas - e alguns amigos mais curiosos - em bailes que frequentei. Homens costumam ter muito mais dificuldade de se deixar conduzir, afinal é um contrassenso à masculinidade hegemônica, um constrangimento ao corpo expressivo masculino que os mais sensíveis conseguem ultrapassar para experimentar as possibilidades que novos lugares corporais têm a oferecer. Mas o que a experiência paterna ensinava é que, ainda que seja um diálogo, há papéis bem definidos na dança de salão - quem conduz e quem é conduzido - que implicam disponibilidades, posturas e intensidades corporais distintas.

Conduzir é ser responsável por imprimir um ritmo e uma direção aos passos da dupla, eleger os caminhos a serem percorridos no salão e manter acesa a criatividade. O desafio de ocupar esta posição está em exercitar a segurança nas escolhas de percurso, transmitindo os movimentos elegidos com clareza e precisão. Por outro lado, o segredo de ser conduzida está em saber se deixar levar. Quando a gente se deixa levar - e encontra um condutor preciso - pode acabar executando, sem se dar conta, passos nunca antes ensaiados. Ser levada é exercitar uma sensibilidade alerta ao toque, mantendo a atenção corporal difusa e aberta às propostas e ao andamento do outro. Deixar-se levar não é tanto se largar, ao contrário, é sustentar, simultaneamente, a entrega e a vigília, cultivando um estado de prontidão para mudanças repentinas de direção.

Alguns elementos podem facilitar ou dificultar a fluidez na dança de um par. O braço que repousa sobre o braço do outro não deve pesar muito, não só porque seria cansativo para os dois, mas por que se perde em flexibilidade. Se as alturas forem muito discrepantes, elas também atrapalham, já que a posição ideal para os braços abertos na lateral é na altura dos ombros, nem muito acima, nem muito abaixo. Observando os pares dançando em um salão rapidamente se identifica os que formaram uma dupla, ou seja, encontraram uma sincronicidade e um diálogo próprio que os permitem compor, ainda que temporariamente, um só corpo. Ao mesmo tempo, há duplas que permanecem dois corpos em separado, cadências atravessadas em semidescompasso.

A memória rítmica da dança ajuda a dar sentido à experiência, aos movimentos e à postura corporal necessária ao ato de ser guiada por um cão. Aprofundo a correlação cinética esboçada com a análise de fotografias feitas durante a fase chamada de "Adaptação". Na mobilidade com cão-guia há todo um posicionamento corporal a ser ajustado entre o cão e a pessoa. O porte do cão precisa corresponder em força e potência ao de quem ele irá conduzir. Nas imagens a seguir, vemos Daniela, uma jovem cega, que, em novembro de 2018, estava fazendo o curso de mobilidade com cão-guia para ser adaptada com Eva, uma labradora de cor preta. Na primeira foto podemos observar a correspondência corporal entre elas. Estão posicionadas para dar início à caminhada dentro do campus do IFC. Daniela segura com a mão esquerda a alça do arreio que Eva está vestindo. Sua perna esquerda está posicionada um passo à frente da direita, alinhada com as patas dianteiras de Eva. Eva está de prontidão, o pescoço esticado para frente, o olhar no horizonte. Daniela fala em um walkie-talkie preso à sua roupa, avisando ao instrutor que estavam prontas para sair. 


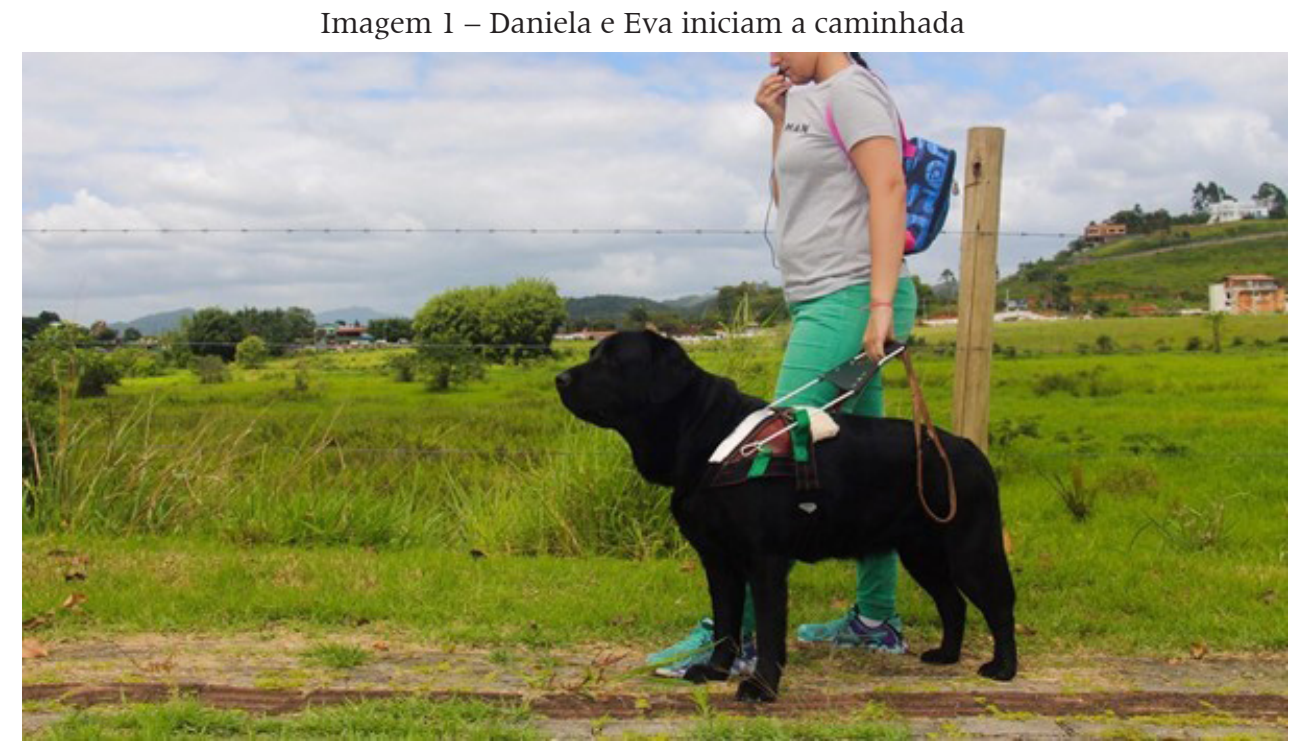

Fonte: Acervo da pesquisadora

Um quesito importante no deslocamento com cão-guia é a velocidade da passada entre o cão e a pessoa, que deve ser aproximada. Um cão mais enérgico e rápido com uma pessoa lenta ou sedentária, é descompasso certo. Na foto seguinte, é possível observar a sincronicidade dos passos de Daniela e Eva. Tirada em um plano mais aproximado, o corpo de Daniela aparece da cintura para baixo. Elas caminham em uma calçada, e a foto registra o momento exato da passada de perna de Daniela, em perfeita harmonia com a passada de patas de Eva.

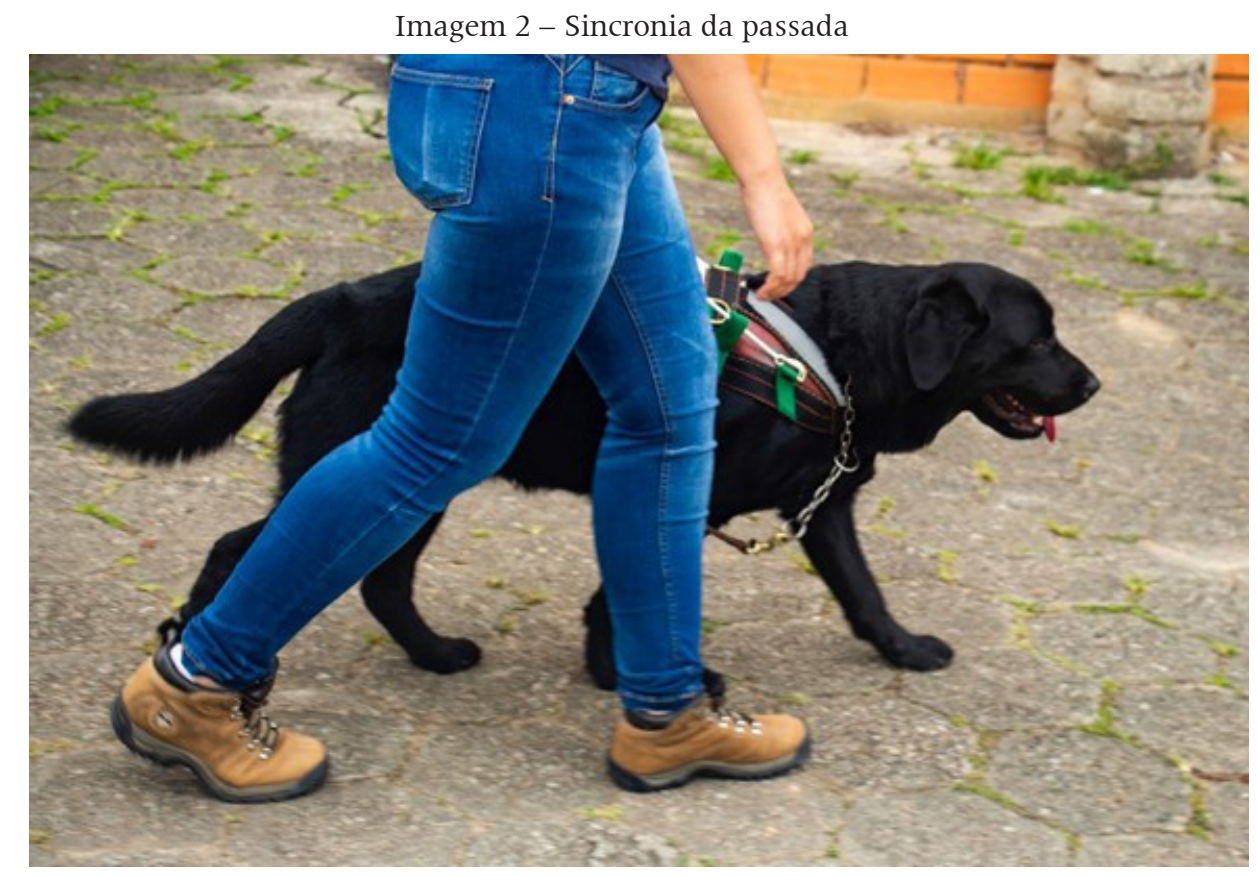

Fonte: Acervo da pesquisadora

Outro elemento a ser observado é o tamanho do arreio e da alça, que deve se adequar à altura da dupla. A forma de segurar também é importante. A alça deve ser 
mantida junto ao corpo, o cotovelo na altura da cintura, antebraço esquerdo inclinado para baixo, o punho na altura do quadril, nem muito rígido nem relaxado demais. Na terceira imagem, em primeiro plano, o objeto de destaque é a mão de Daniela que segura a alça do arreio e a guia em sua mão esquerda, na exata posição descrita.

Imagem 3 - Posição da mão esquerda

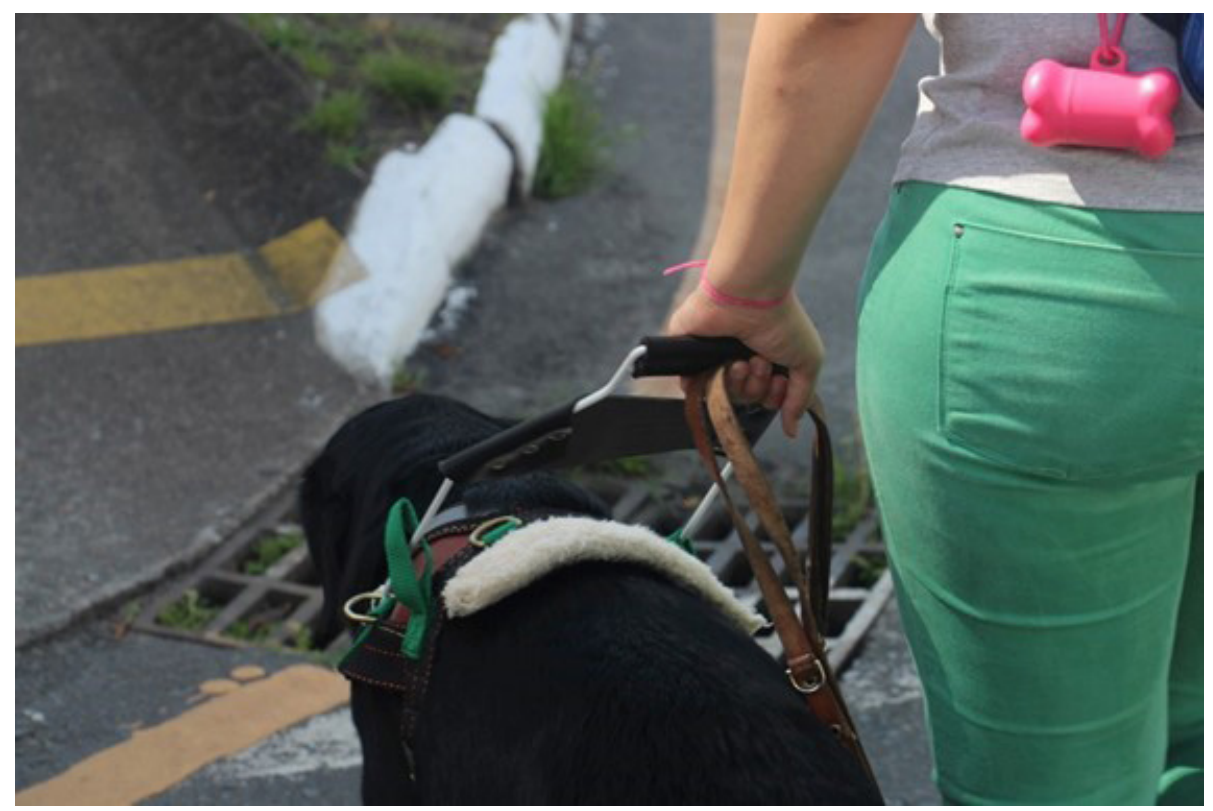

Fonte: Acervo da pesquisadora

Para Gibson, a percepção depende do movimento e, para se desenvolver um conhecimento adequado do ambiente, é necessário um ponto de observação móvel. Assim, "[...] devemos perceber para nos movimentar, mas precisamos também nos mover a fim de perceber" (GIBSON, 2015, p. 213). Ingold (2012) também introduz o fator do movimento para dizer que as coisas em um ambiente adquirem significados a partir da relação prática que uma pessoa, ou um organismo, estabelece com elas. Propõe pensar o ambiente não como algo que exista fora de um organismo autocontido, mas sim como uma zona de interpenetração que está continuamente se fazendo, na medida em que seus habitantes percorrem seus caminhos. Os autores ajudam a compreender o tipo de conhecimento ambulatório que se desenvolve na mobilidade com cão-guia, compreensão que será aprofundada a partir dos depoimentos de Marina, usuária de cão-guia há quatro anos, que fala da relação prática que se estabelece entre ela, o cão, o arreio e o caminho ao longo do deslocamento:

A construção do espaço se baseia mais em sons... e, no próprio trajeto, é meio que o sistema proprioceptor que a gente começa a usar sabe? Por exemplo, eu não tenho nenhuma percepção de luz, mas é sensação do... esqueci o termo técnico, sombreamento, é no sentido de sentir que tem uma presença aqui né, de sentir que eu passei por um poste, eu não encostei no poste, mas eu sinto. Da cinestesia, do movimento... e especialmente a calçada, a estrada, é muito mais a percepção tátil dos pés. Antes, com a bengala, a gente também utiliza bastante dos pés, mas a gente utiliza muito o que a gente sente na vibração da bengala, onde ela bate que chega aqui na mão, que a percepção tátil da mão é muito melhor né? Na verdade, muito mais desenvolvida, não que é muito melhor. Muito mais desenvolvida, é a que a gente utiliza 
mais. E com o cão-guia você tem que utilizar totalmente a sua percepção tátil dos pés e essa visão cinestésica, dessa sensação com o [...] Comigo é mais na parte do rosto, que eu percebo mais, quando passa pelo rosto, quando sente que alguém passou assim por mim, sabe? E é todo um conjunto de ventos que dá. Tipo assim, se eu estou parada na faixa consigo sentir se alguém parou do lado, eu não enxergo nada, mas eu consigo sentir, pelo deslocamento do ar.

A mobilidade com cão-guia é uma prática tátil-cinética habilidosa que envolve um monitoramento entre percepção e ação bastante distinto do deslocamento com a bengala. Na medida em que desenvolve essa nova habilidade, é também um novo conjunto de conhecimentos que vai se desdobrando. Prestar atenção ao sentido do movimento no deslocamento com cão-guia leva a uma reconfiguração do sentido tátil, que não mais se concentra nas mãos, se espalhando por outras partes do corpo. Se antes as informações lhe chegavam aos dedos pela vibração do corpo da bengala, agora são os pés de Marina que ganham relevância na relação perceptiva com o caminho. O chão onde pisa recebe um foco maior de sua atenção e o deslocamento não se dá em um espaço vazio de objetos. Por mais que não se vá de encontro a eles, já que o cão, precisamente, desvia a dupla dos obstáculos, a presença das coisas e dos seres é sentida por sua densidade e pela relação de deslocamento de ar que provocam em um corpo em movimento.

O contato está em todas as atividades de um corpo vivo, quando tocamos somos também tocados. Levando a atenção para os níveis de contato que se estabelecem no corpo que se move em um ambiente, é possível ampliar a sensibilidade e a consciência da percepção tátil (ALEXANDER, 1991). O tato estabelece uma comunicação não verbal entre o cão e a pessoa que se realiza por intermédio da alça do arreio. Por ali se sabe quando há resistência, desvio, direcionamento ou interrupção do movimento. Alexander (1991), no entanto, diferencia tato de contato, considerando que, enquanto o primeiro permanece na superfície da pele, o contato permite que se ultrapasse o limite do corpo para incluir na consciência o campo perceptível do espaço que nos rodeia, mesmo quando não o tocamos diretamente. Cada nova relação de contato que estabelece enquanto se desloca com o cão permite à Marina desenvolver a percepção do ambiente e a consciência da presença dos elementos que o compõe: poste, pessoas, objetos.

Cartografando ventos no rosto, Marina se localiza no espaço. A orientação dos fluxos de ar e a forma como se canalizam nas esquinas a permitem ler diretamente na face as dinâmicas do caminho. Essa não é uma habilidade exclusiva de Marina. Acompanhando a adaptação de Daniela, observo o redirecionamento da atenção que o deslocamento com cão-guia provoca em seu sistema perceptivo. Em uma caminhada rotineira pelas ruas de Balneário Camboriú, ela diminui o passo e pergunta se já havíamos chegado na esquina, mas tínhamos ainda uns 10 metros a percorrer. Pergunto o que a levou àquela impressão, e ela menciona dois fatores, a abertura que sentiu no ambiente e a direção do vento. Observo ao redor e noto um prédio na esquina cuja fachada formava um largo vão na parte baixa, canalizando o ar na paisagem antes do ângulo costumeiro do cruzamento de ruas. Como os Aiviliks, que tem a visão como sentido secundário para orientar seus deslocamentos (LE BRETON, 2016), pessoas cegas também decidem seu caminho pela cidade por meio de elementos de orientação dados por barulhos, odores, direção e força do vento, referências que não são constituídas por objetos ou lugares concretos, mas por relações. 
Reynolds (2017) enfatiza a radicalidade fenomenológica da cegueira como experiência sensorial-perceptiva completa, que classifica como "deficiência criadora de mundo". Para o autor, a experiência da cegueira implica uma reconfiguração muito mais radical da existência do que Merleau-Ponty inicialmente imaginou. Na prática habilidosa de uma pessoa cega bengalante que se desloca em um ambiente, a bengala não é apenas um objeto anexo que estende seu corpo, mas sua corporificação é total, é literal. Pelo depoimento anterior de Marina entendemos que entre bengala e cão-guia há toda uma transformação no movimento, na atenção e na forma de compor perceptivamente o ambiente. Não são simplesmente dois artefatos técnicos isolados para a mobilidade da pessoa com deficiência visual, mas quando postas em uso por um praticante habilidoso também constituem processos dinâmicos distintos de formação de mundos.

Para Sklar (2000), o movimento é uma forma única entre outros meios de expressão. Isso por que nós fazemos e sentimos um movimento de forma concomitante. Pesquisar em movimento é ampliar a consciência para o duplo ato de mover e se sentir movendo. Uma atenção ao fazer que desenvolve ao mesmo tempo uma consciência proprioceptiva. Direcionar a atenção para o modo somático é apreender, como experiência sentida, as dinâmicas cinéticas inerentes aos movimentos. Vivenciar a experiência de mover e me sentir movendo com cão-guia ativa a memória corporificada da dança e a sensação vivida permite apreender a dinâmica cinética inerente a estas duas modalidades de movimento, dançar a dois e se deslocar com cão-guia: a relação de condução.

\section{Ensaiando Passos, Sincronizando Ritmos}

Proponho a imagem da dança a dois para falar do movimento de um cão guiando uma pessoa não apenas pelo elemento poético, mas por remeter tanto à experiência perceptiva e cinética quanto ao exercício de treinamento e repetição necessários para que um cão possa conduzir uma pessoa com segurança, para que seu corpo saiba por onde seguir, que movimentos fazer ao se deparar com diferentes situações, como subir uma escada ou desviar de obstáculos no caminho. São situações que precisaram se tornar corporalidade, ou "importância vivida" (MASSUMI, 2017), para ele. Ao longo de sua vida vão sendo produzidas pelos humanos que o acompanham por meio de uma série contínua de acontecimentos: de forma mais suave, mas já direcionada, na socialização e, de forma mais sistemática, no treinamento (as duas fases distintas do processo de formação de um cão-guia). São ações, simulações e brincadeiras que estimulam uma direção, ou um devir, à sua existência, o de se tornar guia.

Por outro lado, como um dançarino que elabora uma coreografia, durante a fase de adaptação a pessoa cega precisa organizar em seu corpo as relações recorrentes para realizar a performance com o cão, apreender os gestos e as ações que implicam. Como sugere Greiner (2005), um gesto pressupõe um mundo material, além de o evocar. Cada gesto é como um signo que invoca um nexo entre práticas, coisas e as possíveis relações entre elas. No deslocamento com o cão cada gesto invoca um nexo específico entre o arreio, o corpo do cão, o corpo da pessoa e o ambiente, implicando distintas possibilidades de ação: diferentes direcionamentos, mudança de direção, interrupção ou repetição de um movimento. 
Por ocasião de outra temporada em campo pude observar, no pátio de estacionamento em frente à entrada do CTCG, Fernanda, uma jovem mulher cega moradora de Curitiba, e Renato, um dos alunos em formação para ser treinador e instrutor de cão-guia, ensaiando uma série de passos e movimentos. A coreografia que foi ali repetida inúmeras vezes por eles já havia se tornado "importância vivida" para Amorim, pelo conhecimento íntimo que o cão estabeleceu com aqueles movimentos durante o período do treinamento. Por isso a presença canina tinha sido dispensada naquele momento, a fim de poupá-lo do esforço físico. No lugar dele, Renato representava seu papel. Segurando o arreio em uma das pontas, com Fernanda logo atrás sustentando a alça na mão esquerda, Renato ia dando os comandos de forma aleatória, para que Fernanda treinasse os movimentos: "direita", "esquerda", "volta", "direto para o meio fio". Eventualmente, Renato fica imóvel ou vira o corpo para o lado oposto ao comando dado, simulando um desvio do cão, para que Fernanda também treinasse a percepção cinética do erro e o timing da correção ${ }^{4}$. Na imagem seguinte vemos um retrato deste ensaio, com o detalhe para a sincronicidade do movimento de Renato e Fernanda.

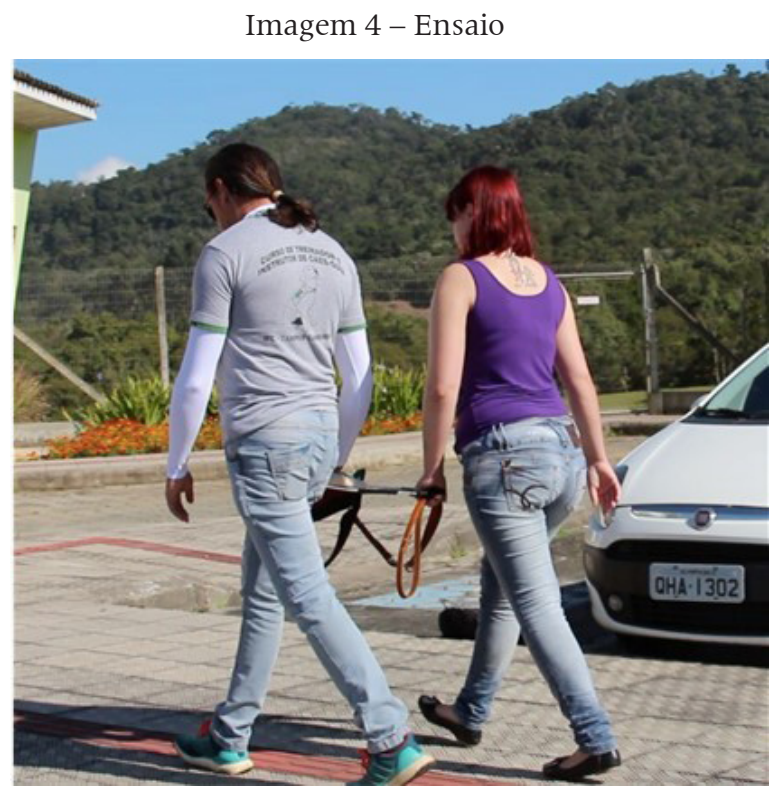

Fonte: Acervo da pesquisadora

Quando é preciso posicionar os corpos para recomeçar a performance, o comando dado ao cão é "um, dois, um dois", executado como num passo de dança. Enquanto canta sonoramente os números, Fernanda deve soltar a alça do arreio e dar dois passos para trás e dois para frente, fazendo um movimento circular com a guia que passa da mão esquerda para a mão direita e depois novamente para a esquerda. O compasso é para que o cão dê a volta completa pelo seu corpo, iniciando pela parte da frente e se reposicionando novamente na lateral esquerda, com o corpo paralelo ao dela. Fernanda executa os passos acompanhados dos gestos das mãos. Uma vez. Duas vezes. Inúmeras vezes. A cada ida e vinda vai aprimorando a precisão dos seus movimentos. É o ensaio do volteio que pode ser observado na próxima imagem:

Sobre a temporalidade da correção e o papel da sintonização do movimento e gesto do treinador ao movimento e ação do cão durante a fase de treinamento, ver Von der Weid (2019b). 


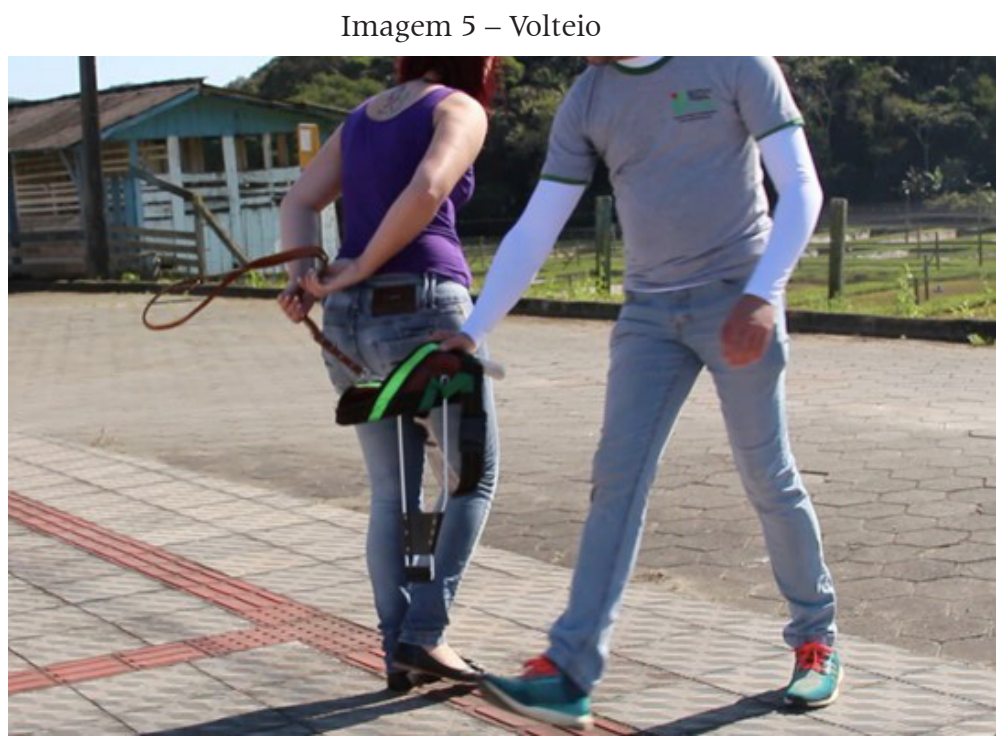

Fonte: Acervo da pesquisadora

Outro momento de ensaio. Com o arreio pendurado em uma grade de ferro e a alça e a guia na mão, Fernanda executa, sob a supervisão de Marcos, o gestual de braço e mão direita, que compõem os movimentos básicos dos comandos "direita" e "esquerda", acrescidos dos respectivos toques de direcionamento que devem ser dados com a alça do arreio na mão esquerda, para que o cão compreenda a direção a seguir. Em primeiro plano vemos a grade e o arreio pendurado nela. Fernanda segura a alça e a mão esquerda de Marcos está apoiada por cima da mão esquerda dela. Ele está posicionado com o corpo por atrás dela e com a sua mão direita segura o braço direito dela indicando, pela propriocepção e pela percepção tátil, o gesto de abertura em leque que deve ser executado com o seu braço direito.

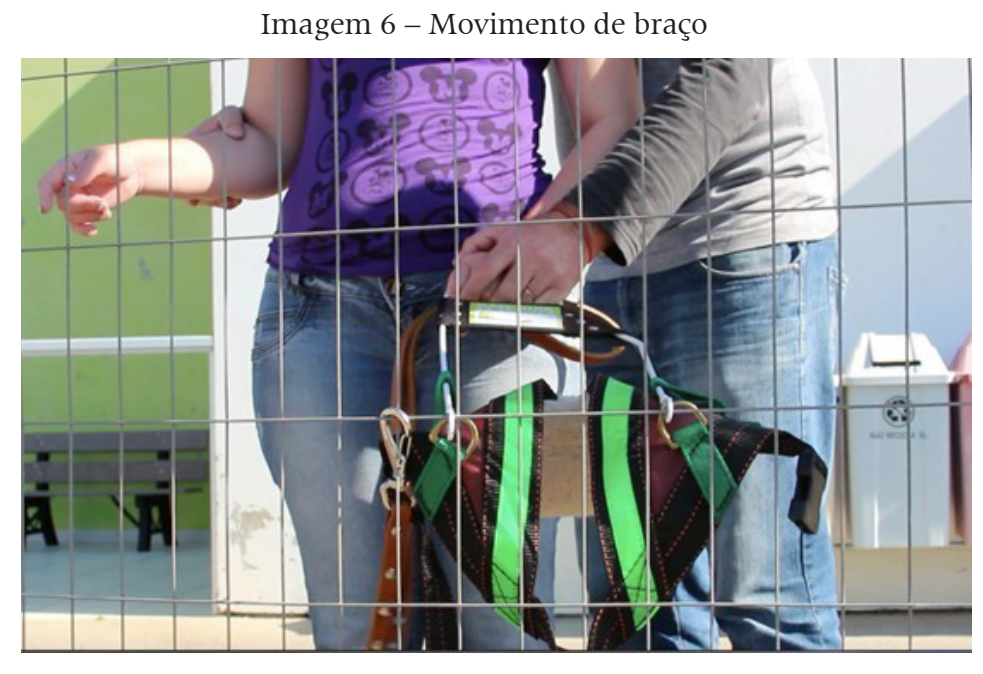

Fonte: Acervo da pesquisadora

A técnica eficaz e verdadeira é, para Vianna (1984), aquela que permite ao bailarino descobrir o seu verdadeiro movimento. Uma conquista que exige reeducação, já que o estudo ou a criação de movimentos não se realiza de modo mecânico ou automático, é um 
processo que deve ser sentido. A forma é necessária para gerar movimento. É na prática da repetição sensível e consciente que a pessoa conquista e desenvolve uma técnica e o seu domínio é que lhe permitirá, futuramente, criar movimentos próprios e espontâneos. Uma boa parceira na dança de salão não é aquela que apenas segue o parceiro, mas que "responde à condução" (ABREU, 2013, p. 103), ou seja, que desenvolve uma forma de comunicação corporal que favorece a conexão do par. Assim como na dança, para alcançar a liberdade da criação na locomoção com o cão é preciso que o corpo saiba primeiro performatizar a técnica e executar com habilidade os gestos e os passos previsíveis. Um dos pré-requisitos para a conexão e a fluidez nos deslocamentos da dupla é tanto que o cão saiba conduzir com precisão quanto que a pessoa cega saiba ser conduzida, ou seja, ambos precisam ter passado por um processo prévio de corporificação da técnica (MAUSS, 2003). Para além da técnica, é preciso também desenvolver a consciência corporal, a postura e um novo equilíbrio no movimento em conjunto, encontrando uma relação de sincronicidade com o corpo e o movimento do outro. Como diz Marina:

[...] muda inclusive pela possibilidade dessa expansão corporal, porque a gente anda com os braços... quando a gente segura na alça, os braços têm que estar aqui (mostra o braço apontando para baixo, a alça na altura da cintura), o peito está aberto, o braço está na lateral. Quando a gente anda com a bengala não, ela já vem aqui para frente do corpo, ela já te limita. E aí pela própria ergométrica que é o próprio arreio tu já ficas numa postura mais imponente sabe? Aí tu consegues caminhar com mais firmeza parece. Essa é a sensação que eu tenho, eu me sinto mais [...] Estava tentando achar outra palavra, mas acho que imponente cabe. Eu consigo andar de cabeça erguida, o peito aberto, nesse sentido. E o equilíbrio ele realmente [...] No começo é uma questão de ajuste e é um aprendizado de leitura corporal do cão, porque às vezes dá a sensação de desequilíbrio, a gente ainda não conheceu o quê que ele está fazendo, se ele está desviando então ter a resposta rápida de desviar junto. Mas é algo construído, é o convivio, e é aquela coisa quanto mais todo dia tu fizer mais vai pegar prática né? E assimé a relação com o cão-guia, quanto mais a gente trabalhar juntos, melhor vai ficar a nossa locomoção juntos.

A fala de Marina sublinha a reorganização da dinâmica postural e o aspecto relacional da forma quando dois corpos interespecíficos se vinculam e se movem juntos. O acoplamento com cão-guia gera um modo próprio de expansão corporal no espaço em que dois seres, em colaboração, se deslocam, se moldam e são moldados um pelo outro, com a mediação de um aparato técnico. É a regularidade das técnicas que vai permitindo que uma prática habilidosa cresça entre a pessoa e o cão (INGOLD, 2015). Ser capaz de se deslocar habilmente com cão-guia é uma ação que emerge de um sistema de forças e de relações que se cria no envolvimento antropozootécnico entre o corpo do cão, o arreio e a pessoa, o sistema todo em movimento em um ambiente também mutável. "Pegar a prática" é desenvolver um "acoplamento íntimo entre percepção e ação" (INGOLD, 2015, p. 105) que possibilita a leitura cinético-corporal e a sintonização de ritmos entre o cão e a pessoa.

Um dançarino quando dança não se move de modo automático, ele cria uma consciência do seu corpo em movimento, evoluindo em um espaço móvel e tensional em que, transformando o seu corpo, é capaz de obter um novo equilíbrio no desequilíbrio (BORGES, 2009). No deslocar-se com cão-guia, é necessário criar uma conscientização do corpo do cão em movimento, a fim de saber, por exemplo, se as tensões do seu corpo no espaço e as variações percebidas em seus gestos são fruto de uma distração ou se são 
parte do exercício da atividade de guiar. Corporificar o movimento do cão ao movimento da pessoa é um ato fisicamente fundado na atenção. Na medida em que se dá ao outro a atenção corporificada, também está se dando a sensibilidade, tocando o espaço e o lugar por ele ocupado. O tato, sempre em mão-dupla, é coextensivo (LITTLE, 2014). Como na dança do Contato Improvisação, o ponto chave para a emergência de uma corporalidade relacional expandida entre a pessoa e o cão é a corporificação da atenção. A doação carnal de atenção ao outro muda radicalmente o potencial da relação. Com a prática habilidosa, o tato ganha articulação em sua escuta e comunicação, em seus conhecimentos e suas habilidades de se fazer conhecido. Os poliritmos da fisicalidade da pessoa se mesclam com os da dupla canina para formar uma só dança.

Embora a performance não seja musicada, há a cadência constante da fala. Na experiência com Morena senti vertigem no começo, não apenas pela adaptação do ponto de equilíbrio do corpo à situação da venda, mas também pela necessidade de manter um fluxo contínuo de comunicação sonora com ela, orientação que recebia de Marcos e que dividia minha atenção. Incentivar a variação no ritmo e na velocidade do nosso caminhar acoplado pelo grau de estímulo e empolgação que imprimia na voz: "vamos lá, garota! No caminho, Morena. Muito bem!". Além da comunicação reforçar o vínculo e regular a velocidade da caminhada, os gestos nessa dança são cadenciados pelos sinais vocais. Marina comenta a sincronização entre gesto e voz no deslocamento com o cão:

\begin{abstract}
Além de sincronizar o nosso movimento com a ação do cão a gente tem que sincronizar o movimento e a fala né? Especialmente depois que o vínculo está estabelecido a gente acaba entrando em situações em que não se faz mais necessário, às vezes eu só faço com a mão às vezes eu só falo. Por exemplo, atravessar uma rua hoje eu só faço assim com a mão (faz o gesto com o braço direito, palma da mão voltada para cima na lateral do corpo, detrás para frente) e não precisa mais nem falar ele já sabe que é o "em frente". Mas isso é com a confiança e o vínculo muito fortes estabelecidos entre os dois, por que é totalmente essencial seguir as orientações que são dadas, por que o cão ele passou por um treinamento, então as condutas dele estão condicionadas àquele gesto e àquelas falas.
\end{abstract}

Se na dança de salão os passos sofrem variação conforme os ritmos musicais, por meio das modalidades de dança - salsa, bolero, samba, forró - no deslocamento com cão-guia são os gestos, corporais e de fala, que influenciam na velocidade e no ritmo de caminhada da dupla. O gestual é tão ou mais importante do que o comando verbal ou "gesto elocutório" (CSORDAS, 2008), embora ambos devam ser executados de forma precisa. Quanto mais expressividade o usuário consegue imprimir em seus gestos, melhor o cão executará os passos desejados. O desafio é que muitas pessoas cegas não tiveram oportunidades para desenvolver não só a flexibilidade, como a própria consciência da expressão corporal. Não falo de um corpo submetido às exigências de uma ação sensóriomotora - seja da saúde, do trabalho, do esporte, das ações cotidianas ou de qualquer outro tipo de atividade -, mas de um corpo que existe como movimento, destacado de todas as determinações práticas, que se abre e se modifica pelos fluxos, ritmos e vibrações que o atravessam. O depoimento de Marina reforça a impressão:

E aí tu vais perceber até na própria postura, no jeito de conseguir se colocar no espaço. Às vezes se a pessoa é um cego novo como a gente diz né, se é um cego fresco, ainda verde, não está maduro ainda, ainda está no processo de descoberta, ainda não está se sentindo pertencente a essa nova realidade então pode estar retraído, vai ter um caminhar mais travado, vai ter 
movimentos mais robóticos, mais firmes. Isso tem muito a ver com as oportunidades de acesso que aquela pessoa teve e com o contexto dela de perda visual e também de atividades que ela faz. Eu fiz esporte né, passei pelo desporto, fiz ballet muito tempo, fiz teatro, então sempre fiz muito uso do meu corpo, eu tenho uma excelente noção de espaço sabe, de me colocar no espaço, e aí isso ajudou bastante.

A disponibilidade corporal necessária para ser conduzido nem sempre flui para a pessoa cega e muitas vezes aparece como ponto de tensionamento na fase de adaptação com o cão-guia. Isso por que a ênfase na funcionalidade no processo de formação de pessoas cegas acaba tendo como efeito reduzir a aprendizagem dos gestos e movimentos à sua eficácia, apartando-as de todo um plano de conectividade e associação presente nos movimentos expressivos. Embora todos os corpos sejam tensionados pelas forças de produtividade que nos disciplinam, corpos que enxergam podem encontrar linhas de fuga para o desenvolvimento de outras formas de viver e se expressar no seu cotidiano ao observarem um filme, uma fotografia ou o desenho grafitado em um muro, por exemplo. O mesmo já não acontece com corpos que não enxergam, que precisam não tanto de explicação verbal, mas de mediação e estímulo ao movimento como ensejo para desenvolver a consciência corporal e expressiva5. O esporte, a dança, o teatro são atividades corporais mencionadas por Marina que estimularam o desenvolvimento tanto de sua expressividade quanto da orientação espacial. Uma oficina de consciência corporal certamente teria efeitos sensíveis para o ajustamento da dupla.

\section{4 "Mover-se em Concerto" com Cão-guia}

Cultivo o hábito de fechar os olhos quando danço a dois. Para mim é nítida a diferença na minha suscetibilidade ao corpo e aos movimentos do outro se estou de olhos abertos ou fechados. Ao fechar os olhos perco o controle visual do salão, confiando ao parceiro a responsabilidade pela condução e por nos desviar de outros corpos e eventuais objetos, como mesas ou cadeiras, que possam obstruir nosso percurso. Na experiência exploratória de andar vendada com a bengala, que realizei no curso de formação em técnica de Orientação e Mobilidade no Instituto Benjamin Constant, lembro de tentar controlar a técnica de manuseio em toque, buscando, com a ponta da bengala, detectar os obstáculos do caminho. O princípio é você se deslocar e, quando encontrar algum entrave, interromper o movimento e identificar a obstrução fazendo a exploração tátil ( seja com as mãos, com os pés ou com a própria bengala), para então se desviar do obstáculo. Com a alça do arreio de Morena em minhas mãos caminhávamos em um vazio, ainda que fosse um vazio cheio de obstáculos, temporariamente invisíveis para mim. Não era preciso se preocupar com a direção ou o que encontraríamos no caminho, mas simplesmente se deixar conduzir. Confiar em sua percepção e caminhada, ajustar o corpo aos seus mais finos movimentos, ser levada sem se largar. Era a performance de uma dança que ali se atualizava. Marina fala sobre sua experiência de andar com Mambo:

Sobre a diferença entre movimento funcional e movimento expressivo nas ações voltadas para pessoas cegas, ver Von der Weid (2019a). 
[...] é a sensação de conseguir andar sem tocar nas coisas. Eu acho que é por isso que muitos de nós usuários descrevemos que a gente tem a sensação de voltar a enxergar quando anda por que é essa não necessidade de tocar nas coisas. E aí isso te remete a como uma pessoa normovisual anda, ela não toca nas coisas né, ela consegue observar todo o entorno só com a visão. E meio que com o cão-guia a gente consegue observar todo o entorno. Porque quando a gente está com a bengala o seu foco está ali; "ai, o que eu vou encontrar? Vai ter um buraco? Vai ter um poste? Vai ter um galho de árvore?". Então você tem que observar muito aqui, na frente (aponta para a área imediatamente próxima ao corpo). E quando eu estou com cãoguia, foi essa a sensação que me deu, eu consigo observar mais amplo, por que eu não preciso me preocupar se eu vou bater nas coisas. [...] Quando a gente está com medo, anda muito retraído, a gente se retrai, e com o cão-guia como tu se sente mais solto, tu libertas mais o seu corpo né, tu se permites ficar mais expansivo, eu senti isso. Eu quando era usuária de bengala era muito tenso, eu não ia de um lugar para o outro relaxada, com tranquilidade. Eu sempre estava tentando construir a próxima ação. E quando eu estou com o Mambo flui.

O movimento, apesar de um processo de mudanças contínuas, possui, para Laban (1978), padrões singulares de ordenações rítmicas. O autor desenvolve uma espécie de partitura de movimento, semelhante à partitura musical, que possibilita diversas interpretações teórico/corporais. O fluxo é um dos quatro fatores do movimento analisados por Laban e suas observações nos ajudam a compreender a mudança na qualidade do movimento entre o deslocamento com a bengala e com o cão mencionada por Marina. A fluência está relacionada ao grau de liberação que se produz em um movimento e também comporta as caracterizações de pausas ou paradas e, ainda, de resistência e contramovimento. No deslocamento com a bengala temos uma fluência controlada que confere ao movimento a qualidade de restrição, uma prontidão interna para, a qualquer momento, parar a ação em função de alguma obstrução encontrada no caminho. Já com o cão-guia a sensação descrita por Marina é de fluidez do movimento, sensação que também se relaciona à facilidade de realizar uma mudança, mas manter a continuidade do fluxo, mesmo quando é necessário se desviar de obstáculos.

Marina também menciona a alteração de tônus muscular entre a bengala e o cão-guia, de um estado de fechamento e tensão para um estado mais solto e relaxado, mudança que terá reverberações não só na qualidade do seu movimento, mas também na amplitude de sua percepção espacial. Confiar o corpo à condução do cão libera sua atenção ao longo do deslocamento para se dirigir a lugares mais distantes do que o espaço circunscrito ao redor do corpo, delimitado pelo comprimento da bengala. Little (2014) propõe considerarmos o direcionamento da atenção como uma prática corporificada capaz de gerar novos sentidos do self, abrindo dinâmicas relacionais criativas. A atenção é formativa da experiência e das possibilidades do movimento. Estender a si próprio na direção do parceiro de dança pode provocar repercussões da ação que são sentidas em sua corporificação. Dar atenção é uma ação que potencializa a entidade que a recebe, um ato de alinhamento com o que quer que esteja recebendo a atenção, no caso em questão, o cão. Sewall (1999) propõe considerar a atenção como alinhamento, o que amplifica o seu aspecto direcional: para onde quer que nossa atenção se dirija, é para lá que vamos. Da bengala ao cão-guia podemos observar uma mudança significativa na orientação corporificada da atenção, o que permite a Marina novos alinhamentos direcionais no espaço. 
Como em uma dança a dois, há papéis bem definidos na mobilidade com cãoguia e ser conduzido é saber abrir mão do protagonismo, se colocar em segundo plano, entregando os seus movimentos à escolha canina, um gesto de confiança que só se aprende a cultivar na prática. Sobre a diferença técnica, cinética e perceptiva entre o deslocamento com a bengala e o deslocamento com cão-guia, Marina relata:

Colocar a sua locomoção, dividir a responsabilidade da sua locomoção com ele. Tu não és mais o ator principal da sua orientação e mobilidade, porque quando tu estás com a bengala, tu que manda. A bengala ela é um instrumento, uma extensão do seu dedo. Então tu que está encostando nos objetos, tu que bate no obstáculo, aí tu que contorna o obstáculo, decide como é que vai passar por ali ou não vai [...] Então tu és o protagonista. E, com o cão-guia, você é a dupla, você é o segundo elemento naquele processo, mas as principais tomadas de decisão vêm do cão.

Marina ressalta o papel diferenciado entre quem conduz e quem é conduzido no bailado do deslocamento com o cão. Nesse par interespecífico, o protagonismo da condução é canino. Ainda que a escolha do destino seja dela, é ele que toma as decisões de percurso, desvia dos outros corpos e obstáculos no caminho, imprime o ritmo e o direcionamento da dupla nesse palco que é rua. Como lembram Gonçalves e Osório (2012), tanto Boas quanto Radcliffe-Brown atribuíram ao ritmo o caráter essencial da expressão artística da dança. Para o último, a principal função da natureza rítmica da dança seria a de propiciar a união de um determinado número de pessoas em torno das mesmas ações, agindo como um só corpo. Não por acaso, o ritmo e a velocidade da caminhada são quesitos fundamentais para se avaliar a harmonia provável de uma dupla. Aos poucos vai se desenvolvendo uma empatia somática (MILLER, 2019) entre a pessoa e o cão, que cria uma relação de reconhecimento, compreensão física e sintonia entre eles. Marina comenta sobre a qualidade rítmica de sua dança com Mambo:

Nós temos um ritmo rápido que, é muito interessante, foi uma das tantas características que fez a nossa união de dupla né, porque o Mambo já vinha com uma predisposição muito rápida de caminhar, e eles viram que isso também fazia parte de mim. [...] Foi desde o começo. Desde aquele primeiro dia a gente já conseguiu alinhar o caminhar juntos, foi muito rápido mesmo.

Sheets-Johnstone (2017) usa a expressão moving in concert para se referir à habilidade dos seres de se moverem harmoniosamente em conjunto no contexto da dança, unindo a sua atenção à atenção de outros, de forma direcionada e recíproca. Para mover-se em concerto, os dançarinos precisam pensar em movimento, desenvolvendo consciência corporal e conhecimento tanto da dinâmica do próprio movimento como da dinâmica do movimento do outro. Um modo primário de pensamento que envolve os sistemas cinestésico e tátil. Significa estar vivo para o fluxo contínuo do movimento que se transmite experiencialmente, pela dinâmica puramente qualitativa que constitui uma dança. Com Morena nosso "movimento em concerto" era silencioso, mas ainda assim a dinâmica tinha espaço e tempo definidos: saímos de um lugar para outro e a performance teve a duração do deslocamento. Pisar onde ela pisa, girar quando gira, seguir seus passos. Era como uma dança.

O instrutor Marcos comenta que mesmo depois de terminada a adaptação, quando o par pessoa-cão já começa a trabalhar sem o acompanhamento de um instrutor, leva pelo 
menos um ano para que o vínculo esteja efetivamente formado e a relação se consolide. Formar uma dupla é como alcançar o estágio do improviso na dança. Para chegar lá é preciso que os bailarinos tenham vivenciado aquela situação inúmeras vezes, que seu corpo tenha se movimentado e explorado suas capacidades, que tenham repetido os gestos, incorporado os passos e naturalizado a coreografia.

Com tempo e prática o ajuste corporal vai se afinando entre o cão e a pessoa e, aos poucos, o que eram dois vai se tornando um. Vagarosamente o cão e a pessoa descobrem formas de estar juntos, de se mover juntos, de se comunicar com habilidade ou "espontaneidade disciplinada". Como lembra Haraway (2008), é uma questão de identificar quais gestos, ações e atitudes facilitam ou bloqueiam a confiança. A aprendizagem nunca cessa. O cão tem que exercer a atividade para continuar sendo guia. Quanto mais exerce, melhor guia se torna. O aprimoramento é da dupla, eles trabalham juntos, alcançam as coisas juntos. O guia não existe sem aquele que conduz. Há aqui um compartilhamento da confiança, do ritmo corporal dos passos, da responsabilidade e da própria decisão no agenciamento antropozootécnico que é a mobilidade com cão-guia. São situações de sobreposição e extensão de subjetividades, como sugere Despret (2004). O cão guiará em nome de um "nós" constituído por uma composição de seres, humano e canino, equipado com um aparato especialmente desenhado com o fim de ensiná-lo a guiar.

Manning e Massumi (2014) propõem compreender uma técnica como um modo de engajamento com as modalidades de expressão que uma prática, por si própria, inventa. Práticas experimentais corporificam uma técnica para catalisar um acontecimento, cujos exatos contornos não podem ser antevistos. O conceito de técnica dos autores se aproxima ao de Gilbert Simondon por incluir as condições pelas quais uma prática adquire uma expressão técnica definida. Uma técnica é processual, ela reinventa a si mesma na evolução da prática. A chave está menos nos fins antevistos - ou qualquer tipo de estrutura subjetiva intencional - do que em como são colocadas as condições iniciais para que um desdobramento aconteça. Tal compreensão nos ajuda a pensar os processos de aprendizagem no deslocamento com cão-guia durante a fase de adaptação. Ali são colocadas as condições iniciais (os gestos, os roteiros urbanos, o aparato do arreio, o movimento das caminhadas) por meio das quais uma prática - o deslocamento pessoacão - pode adquirir uma expressão técnica definida. Os contornos desse acontecimento - a formação de uma "dupla" singular - não podem ser antevistos pois não há como prever as inúmeras situações que irão enfrentar em seu dia a dia, ou mesmo os modos corporais singulares de comunicação que cada dupla posteriormente desenvolve a partir de um processo de familiarização. Tanto o treinamento quanto a fase de adaptação vão propondo condicionamentos para o cão e para a pessoa, e modos de engajamento entre eles que, processualmente, na contínua reinvenção que acontece na prática, vão permitindo a emergência de uma nova modalidade técnica: uma dupla em deslocamento. 


\section{Por uma Escrita Sensória e Movente}

"A pele deles vê, como uma cauda de pavão" (MICHEL SERRES, 2001, p. 32)

Como sugere Manning (2009), quando damos um passo, a forma como aquele passo te move é um elemento-chave para determinar até onde se pode ir. O corpo devém por meio de forças que se recombinam para compor potenciais direções. Este artigo, e a pesquisa que lhe deu origem, foram forjados em movimento. Desde o início deixei-me afetar pela cegueira, disponibilizando meu corpo ao movimento sem o apoio conhecido da visão. Essa não foi, no entanto, uma abordagem premeditada, não sabia dizer para onde o movimento levaria, apenas que ele tinha sido ativado. Tenho consciência e convicção de que são apenas as relações e o que elas moveram - física e afetivamente - que autorizam a dizer o que falo, a pensar o que penso. A relação é, então, meu lugar de enunciação, via de entrada em um universo que acessei pelo caminho do afeto - pela confiança e amizade que criei com pessoas cegas e pela forma como me deixei afetar pela não-visão (FAVRET-SAADA, 2005).

A cegueira ensina que há todo um mundo sensorial e perceptivo relevante, que não pode ser sobreposto ao mundo relevante da visualidade, mas, antes, deve ser revelado em toda a sua especificidade, dores, beleza e complexidade. Conhecer tais universos ressaltando suas diferenças, e não a similitude com as experiências centradas na visão, é uma aposta que tenho desenvolvido. A cegueira conduz ao esforço de descolonização não só das formas habituais de agir e fazer coisas no universo cotidiano, mas do próprio modo de proceder o conhecimento em antropologia. Tanto pelo foco excessivamente visual do método etnográfico quanto pela metáfora excessivamente visual de certos conceitos que utilizamos para aludir ao modo de existência dos outros que pesquisamos - ponto de vista, perspectiva, visão de mundo. A etnografia tem muito a se beneficiar da cegueira como "recurso positivo" (DEVOS, 2018), já que é uma condição de diversidade corporal que inevitavelmente traz consigo práticas sensoriais particulares e certos tipos de conhecimento potencialmente disruptivos das normatividades metodológicas.

A cegueira aparece então como um disparador, um dispositivo que abre o campo do sensorial, das intensidades, como objeto de investigação e universo de sentido. A cegueira aqui entendida como diferença, como modo de existência que conduz a percepções, movimentos, práticas e poéticas. Como a teoria em antropologia é etnográfica, a singularidade da cegueira tem levado a uma reflexão sobre a escrita, em busca de criar uma coerência entre o fenômeno que está sendo revelado, o modo de aceder a esse conhecimento e a maneira de comunica-lo. Ou seja, uma coerência entre: 1) a cegueira revelada enquanto modo de existência singular; 2) o aprendizado das práticas do conhecer tátil, empreendendo corporalmente a visita a este estado perceptivo a fim de compreendelo "de dentro" (INGOLD, 2015); e 3) a forma de traduzir esse conhecimento, fazendo com que a escrita também tenha uma estética tátil, uma cadência tátil. Dora, uma das pessoas cegas que participou da pesquisa de doutorado (VON DER WEID, 2014), comenta a diferença entre os modos perceptivos táteis e visuais que pode ser aqui sobreposta a um modo tátil de proceder a escrita e o conhecimento: "A visão é um sentido sintético, você 
chega e no mesmo minuto você já viu tudo, pelo menos você já viu o contexto. E o tato é analítico, para eu poder ter o contexto eu tenho que ir parte por parte, para poder montar aquele contexto na minha cabeça". Uma escrita que não toma distância, menos preocupada em captar de imediato a totalidade de um fenômeno, mas que constrói o conhecimento parte por parte, imersa em proximidade, atenta aos detalhes que se apreende com o corpo inteiro nessa percepção de curto alcance que é o tato. Como já disse Bavcar (2003), o tato é o "olhar aproximado", um modo de perceber e conhecer de quem é diretamente afetado em sua zona corporal de contato.

Sousa (2004) chamou de "mundividência tátil" um modo particular de ser, perceber e estar no mundo que contém suas próprias especificidades: o caráter sequencial e analítico da exploração tátil, a temporalidade mais lenta, a proximidade, o engajamento, a importância dos detalhes. São dinâmicas sensoriais e de movimento que são primeiro vivenciadas na fisicalidade, para então serem relatadas acionando a experiência da interação com todo o corpo. Uma característica singular do tato em relação a outras modalidades perceptivas é que aquilo que toco também me toca, o que implica uma fusão parcial entre sujeito e objeto (HSU, 2000). Tenho procurado, a partir de uma postura de abertura e engajamento com as práticas e o universo perceptivo da não visão, gerar imagens e representações que, esteticamente, sejam também afetadas pelas atmosferas experimentadas, fazendo habitar a escrita etnográfica de sentidos e percepções para além da visualidade. Deixar contaminar a escrita por uma visão de dentro, de quem submerge na interação. Não o olhar de fora, contemplativo e à distância, mas o olhar de quem recebe a pressão das coisas na epiderme, acariciando o mundo e se deixando acariciar por ele (SERRES, 2001).

Se a produção de imagens e a faculdade de imaginar não estão unicamente relacionadas ao visual, a possibilidade de representar pode adquirir contornos materiais, táteis, auditivos, cinéticos ou temporais próprios ao universo pesquisado, revelando novas medidas para o mundo. A associação da visão com a visualização parece ofuscar os múltiplos significados embutidos na palavra imagem. Dora fala sobre o aspecto polissêmico da imagem:

É que imagem para mim ela não é só visual. Pode ser uma imagem auditiva... imagina aquela música, imagina o som de harpa. Pode ser uma imagem tátil, imagina aquele lençol de seda. Pode ser uma imagem olfativa - 'imagina aquele chocolate com baunilha'. Ou pode ser uma imagem gustativa e até pode ser uma imagem proprioceptiva - 'imagina que você está pulando de um trampolim', é uma imagem proprioceptiva, ela não é tátil, não é exatamente nenhum dos cinco sentidos. $\mathrm{E}$ pode ser - 'imagina que você está triste'. Então imagem é uma coisa muito rica. A gente tem uma cultura que é predominantemente visual, que bota tudo no visual, visualiza tudo e acha que com a visão vai resolver.

Fiquemos com a imagem de movimento, a que mais enfatizei neste artigo. Dora revela que a imagem de uma pessoa pulando em um trampolim pode ser lembrada não somente por sua qualidade visual, mas por sua sensação essencialmente cinética: a ação que informa a palavra "pular". Com tal imagem proprioceptiva em mente, o que fiz ao longo do artigo foi descrever menos o aspecto visual da observação do deslocamento com cão-guia e mais trazer a atenção somática para a sensação cinética presente na palavra 
"guiar". Como indica Sklar (2000), um treinamento prévio em movimento permite que o movedor distinga nuances entre dinâmicas distintas, que as sinta como sensações cinéticas, as reconheça no movimento de outros e perceba suas reverberações em palavras. Foi a experiência anterior com o universo do movimento que permitiu, por meio das sensações cinéticas que o deslocamento com cão-guia provoca, que reconhecesse ali certas dinâmicas presentes na dança de salão: conduzir e ser conduzido. Realizo, assim, uma espécie de investigação somática (FERNANDES, 2019), modalidade de pesquisa que inclui a imersão em um ambiente vivo como princípio fundamental, integrando, em tempo real, experiência e análise. Ao transformar o movimento corporal em uma técnica de pesquisa procura-se diluir a separação tradicional entre sujeito e objeto, gerando um modo relacional e dinâmico de criar conhecimento.

Ao trazer para a escrita a analogia tátil-cinética vivida procuro produzir atmosferas imagéticas que retratem as qualidades sensíveis das experiências. A escrita é também um lugar para investigar processos de produção de representações que não estão estruturadas pela determinação visual, mas respondem ao estímulo de outras práticas perceptivas. Sklar (2000) nos lembra que, a despeito do cliché de que aquilo que é dançado não pode ser falado, os efeitos transformativos do movimento não são necessariamente inefáveis. As palavras podem se tornar permeáveis às reverberações somáticas. O que se procura encontrar são palavras que revelam sensações. Produzir "imagens de imagens" (SOULAGES, 2017) que deem a ver ao leitor as experiências extravisuais do mundo de pessoas cegas: no caso deste artigo, imagens de imagens táteis, imagens de imagens cinéticas. Com isso, o que se busca ampliar são os próprios parâmetros sensíveis da realidade, estabelecendo, pelos referenciais sensoriais que vazam do papel, ligações que talvez não se realizassem naquele contexto caso fosse experimentado e descrito apenas visualmente.

O tipo de encontro que tenho com pessoas cegas ensina todos os dias a me descolar dos padrões corporais que chamamos de normalidade, a querer expandir os horizontes sensoriais, estéticos e políticos da realidade. A antropologia, conforme venho praticando, se aproxima bastante da arte, não tanto por analisar as expressões culturais e artísticas dos grupos, mas porque se debruça criativamente sobre a experiência, desenvolvendo um saber encarnado, que se deixa tocar pelo que lhe acontece, no trabalho de campo e também na vida. Um modo de investigação que usa o próprio corpo como ferramenta para conhecer - ferramenta para formular questões - como meio para criar uma relação que proporcione novos conhecimentos. Práticas que criam e transformam pela sintonia, corpo que vai sendo articulado e ampliado pelos afetos.

Procuro, com isso, desenvolver uma aproximação às formas de estar no mundo de pessoas cegas sem pressupor uma assimetria radical nas relações entre pessoas que enxergam e pessoas que não enxergam. A cegueira, e as questões que ela traz, são abordadas como potencialidades do humano, nem sempre realizadas por pessoas que enxergam pelo sobrepeso que se dá ao sentido visual nas formas de socialização. Trato os olhos de quem não vê muito mais como um equipamento distintivo, que dota aquele que não enxerga de afecções e capacidades singulares, do que como uma essência incapacitante de cegueira, representação projetada de corpos visualmente situados. 
As práticas e as vivências cotidianas são o solo do conhecimento que se busca desvendar sobre o universo sensorial da cegueira, levando adiante uma investigação sobre o papel da percepção no desenvolvimento dos modos de vida. A experiência já é aqui considerada uma forma de pensamento e a cegueira é tratada como uma filosofia encarnada: um conjunto de saberes que se desenvolvem na ação, por meio da aprendizagem e invenção de técnicas corporais (MAUSS, 2003). Busco criar, assim, na metodologia e na escrita, uma forma de equivalência, um espaço onde a visão e a cegueira possam entrar em diálogo como duas modalidades ontológicas sensoriais distintas, traduzindo e transpondo as modalidades perceptivas e os mundos sensíveis por elas gerados. Como indica Viveiros de Castro (2004), traduzir não é desfazer o equívoco, isso seria supor que ele nunca existiu em primeiro lugar - tornar a cegueira funcionalmente equivalente à visualidade. Uma tradução ontológica da ordem sensorial da cegueira não tem como objetivo encontrar sinônimos ou equivalências nas formas visuocêntricas de perceber o mundo para as formas com que pessoas cegas o percebem - caminhos "alternativos", mais "lentos" ou "atrasados", para se fazer as "mesmas" coisas ${ }^{6}$. Ao invés disso o objetivo é não perder de vista a diferença oculta nos homônimos equívocos (VIVEIROS DE CASTRO, 2004), entre as formas de fazer da cegueira e as formas de fazer da visão. Traduzir seria, então, justamente o oposto, enfatizar ou potencializar o equívoco, abrir e ampliar o espaço imaginado para não existir entre as duas ordens sensoriais em contato, espaço que o equívoco precisamente oculta.

Costuma-se conceber o ato de relacionar ordens sensoriais distintas nas deficiências descartando-se as diferenças em favor das similaridades ou de sua aproximação (o "as if" de Winance, 2007). Uma abordagem ontológica propõe encarar esse processo por outro ângulo: o oposto da diferença na deficiência não é a eficiência ou a normalidade, mas a indiferença. Por isso que a diferença na deficiência não pode desaparecer, ela não deve ser desfeita porque desfazê-la é aprisionar pessoas com deficiência em uma existência fadada ao fracasso ou, ainda pior, à exclusão e à dependência. Ao invés de tentar desfazer o equívoco pela via da normatização, fundando o binarismo normal $\mathrm{X}$ anormal como efeito colateral do disfarce, a cegueira, e acredito que outras formas de diferença que foram classificadas como "deficiência", nos convidam a estabelecer vínculos em que a diferença seja o princípio da relacionalidade (VIVEIROS DE CASTRO, 2004). Diferenciar a indiferença, inserir a multiplicidade corporal onde a identidade corponormativa era antes presumida - nos prédios e construções, nos produtos e soluções tecnológicas, nas pedagogias e nas técnicas, nos parâmetros estéticos, nas ruas, nos sinais e nas calçadas, nos padrões de interação entre as pessoas.

Se olharmos para a cegueira como uma forma de construir corpos que habitam mundos, não mais como fenômeno a ser distinguido da normalidade ou como uma forma associada à falta ou ao extraordinário, podemos inverter a relação cognitiva (LAGROU, 2011). A capacidade pode ser então redefinida como palavra que expressa a habilidade de uma pessoa - uma corporalidade - agir sobre o mundo, de criá-lo e transformá-lo.

\footnotetext{
Como lembra Winance (2007), a principal estratégia para se lidar com a diferença da deficiência, no modelo medico, tem sido buscar um alinhamento do corpo deficiente com uma norma pré-definida o que, para a pessoa com deficiência, só é possível por meio da construção de um "como se" (as if), uma vez que o afastamento da norma social é consequência de uma condição corporal que não pode ser totalmente removida. Nesse modelo de normalização, a diferença da deficiência é construída como falta, perda ou ausência.
} 
A marca da cegueira no corpo pode ser compreendida como um instrumento de ação, que age sobre o próprio corpo. Mas para isso não basta ter um corpo cego, é preciso criar uma corporificação. A infraestrutura da cegueira - o aparato técnico, as práticas, os manuais, os cães e os artigos científicos - permite operar a construção de um mundo. O papel dos exercícios e dos jogos na (re)habilitação (ou na estimulação essencial, o equivalente para pessoas que nascem cegas) seria, então, o de ajudar a produzir um corpo em relação construtiva com os fluxos que o atravessam. A cegueira se torna, assim, visualidade perspectiva - por meio de um processo de corporificação. Quando a cegueira se torna perspectiva ela deixa de ser déficit e se consolida como um mundo sensorial singular: um modo - uma corporalidade - uma potência específica.

Por meio de experimentações com as corporalidades nativas, através do desempenho de ações, movimentos e práticas, busco desenvolver formas de agir e pensar com a cegueira. Tomar suas formas de estar no mundo - suas corporalidades - como interlocutoras, as vezes polêmicas, as vezes antagonistas, a outras formas de estar e perceber o mundo. Nesse sentido, é possível aproximar o tipo particular de perspectivismo que desenvolvo ao desvelado por Lapoujade (2013) na filosofia bergsoniana: aquele que entra naquilo que se faz, segue o ser movente, adota seu devir, ressaltando a diferença interna dessa ou daquela realidade, estabelecendo uma analogia entre os seus próprios movimentos interiores e os movimentos do outro. Ao invés de observar de fora, entrar no interior de outro ponto de vista, estabelecer uma relação com outras realidades, embarcar na sua perspectiva até onde seja possível ajustar as vibrações, buscar a sincronização que está sempre se fazendo - e se desfazendo - entre ritmos distintos de duração. Segundo Lapoujade (2013, p. 69), para Bergson, "[...] conhecer é sempre entrar em um movimento, como nos emocionamos com uma melodia ou como entramos em uma dança".

\section{Agradecimentos}

Devo um agradecimento especial a Viviane Vedana e Gabriel Coutinho, organizadores da mesa, pelo convite, e aos demais colegas que compuseram a mesa pelo momento enriquecedor de troca e diálogo.

Agradeço também aos professores, treinadores, alunos e funcionários do CTCGIFC-Camboriú pela abertura e acolhimento a este projeto de pesquisa.

\section{Referências}

ABREU, Fernanda F. de. O par como unidade criativa: reflexões sobre criação e técnica na dança de salão. Textos Escolhidos de Cultura e de Arte Populares, Rio de Janeiro, v. 10, n. 1, p. 101-112, 2013.

ALEXANDER, Gerda. Eutonia: um caminho para a percepção corporal. São Paulo: Martins Fontes, 1991.

BAVCAR, Evgen. O corpo, espelho partido da história. In: NOVAES, A. (org.). O homem Máquina: a ciência manipula o corpo. São Paulo: Companhia das Letras, 2003. p. 175-190.

BORGES, Hélia. Sobre o movimento: o corpo e a clínica. 2009. 200f. Tese (Doutorado) Universidade do Estado do Rio de Janeiro, Instituto de Medicina Social, Rio de Janeiro, 2009. 
CANDEA, Matei. Endo/Exo. Common Knowledge, [s.l.], v. 17, n. 1, p. 146-150, 2011.

CSORDAS, Thomas. Corpo/Significado/Cura. Porto Alegre: editora UFRGS, 2008.

DEVOS, Piet. Dancing beyond sight: how blindness shakes up the senses of dance. Disability Studies Quarterly, [s.l.], v. 38, n. 3, 2018.

DESPRET, Vinciane. The body we care for: figures of anthropo-zoo-genesis. Body $\boldsymbol{\sigma}$ Society, [s.l.], v. 10, n. 2-3, p. 111-134, 2004.

FAVRET-SAADA, Jeanne. Ser afetado. Cadernos de Campo, [s.l.], v. 13, p. 155-161, 2005.

FERNANDES, Ciane. Somática como pesquisa. In: CUNHA, Carla; PIZARRO, Diego; VELLOZO, Marila Annibelli (org.). Práticas somáticas em dança. Brasília, DF: Editora IFB, 2019. p. $121-138$.

FOUCAULT, Michel. Os anormais. São Paulo: Martins Fontes, 2010.

GIBSON, James J. The ecological approach to visual perception. New York: Psychology Press, 2015.

GONÇALVES, Renata de Sá; OSORIO, Patrícia S. Dossiê Antropologia da dança: apresentação. Antropolítica, Niterói, n. 33, p. 13-23, 2012.

GREINER, Christine. O corpo: pistas para estudos indisciplinares. São Paulo: Annablume, 2005.

HARAWAY, Donna J. When species meet. Minneapolis: Minnesota Press, 2008.

HSU, Elisabeth. Towards a science of touch. Anthropology $\boldsymbol{\&}$ Medicine, [s.l.], v. 7, n. 2, p. 251-268, 2000.

HUGHES, Bill. Civilising Modernity and the Ontological Invalidation of Disabled People. In: GOODLEY, Dan; HUGHES, Bill; DAVIS, Lennard (dir.). Disability and social theory, Hampshire, Palgrave, 2012. p. 17-32.

HULL, John M. Reconizing another world. The National Journal for People with Disability, [s.l.], v. 3, n. 2, p. 23-26, 2001.

INGOLD, Tim. Ambientes para la vida. Montevideo: Ediciones Trilce \& UDELAR, 2012.

INGOLD, Tim. Estar Vivo. Petrópolis: Vozes, 2015.

LABAN, Rudolf. Domínio do movimento. São Paulo: Summus, 1978.

LAGROU, Els. Existiria uma arte das sociedades contra o Estado? Revista de Antropologia, [s.l.], v. 54, n. 2, p. 747-780, 2011.

LAPOUJADE, David. Potências do tempo. São Paulo: n-1 Edições, 2013.

LATOUR, Bruno. How to talk about the body? Body \& Society, [s.l.], v. 10, n. 2-3, p. 205-229, 2004.

LE BRETON, David. Antropologia do corpo e modernidade. Petrópolis: Vozes, 2011.

LE BRETON, David. Antropologia dos sentidos. Petrópolis: Vozes, 2016.

LITTLE, Nita. Restructuring the selfsensing: attention training in contact improvisation. Journal of Dance \& Somatic Practices, [s.l.], v. 6, n. 2, p. 247-260, 2014.

MANNING, Erin. Relationscapes. Massachusetts: MIT Press, 2009.

MANNING, Erin; MASSUMI, Brian. Thought in the act. Minneapolis: Minnesota Press, 2014.

MASSUMI, Brian. O que os animais nos ensinam sobre política. São Paulo: n-1 Edições, 2017. 
MAUSS, Marcel. As técnicas do corpo. In: MAUSS, Marcel. Sociologia e Antropologia. São Paulo: Cosac \& Naify, 2003. p. 401-424.

MILLER, Gill Wright. Feminismo e práxis somática. In: CUNHA, Carla; PIZARRO, Diego; VELLOZO, Marila Annibelli (org.). Práticas somáticas em dança. Brasília: Editora IFB, 2019. p. 65-78.

NIETZSCHE, F. Fragmentos póstumos: 1884-1885: volume V. Tradução Marco Antônio Casanova. Rio de Janeiro: Forense Universitária, 2015.

OVERBOE, James. Theory, impairment and impersonal singularities. In: GOODLEY, D.; HUGHES, B.; DAVIS, L. Disability and social theory. Hampshire: Palgrave, 2012. p. 112-126. PORCO, Alex S. Throw yo' Voice out: Disability as a Desirable Practice in Hip-Hop Vocal Performance. Disability Studies Quarterly, [s.l.], v. 34, n. 4, 2014.

REYNOLDS, Joel M. Merleau-Ponty, World-Creating Blindness, and the Phenomenology of Non-Normate Bodies. Chiasmi International, [s.l.], v. 19, p. 419-434, 2017.

SERRES, Michel. Os cinco sentidos: filosofia dos corpos misturados. Rio de Janeiro: Bertrand Brasil, 2001.

SEWALL, Laura. Sight and Sensibility. New York, NY: Penguin Putnam, 1999.

SHEETS-JOHNSTONE, Maxine. Moving in Concert. Choros International Dance Journal, [s.l.], v. 6, p. 1-19, 2017.

SKLAR, Deidre. Reprise: on dance ethnography. Dance Research Journal, [s.l.], v. 32, n. 1, p. 70-77, 2000.

SOULAGES, François. A fotograficidade: como reflexão sobre as imagens (de imagens).

Revista Farol, [s.l.], n. 18, p. 142-151, 2017.

SOUSA, Joana B. de. Aspectos comunicativos da percepção tátil. 2004. 176f. Tese (Doutorado em Comunicação e Semiótica) - Programa de Pós-Graduação em Comunicação e Semiótica, Pontifícia Universidade Católica de São Paulo, São Paulo, 2004.

TOREN, Christina. Antropologia e psicologia. Revista Brasileira de Ciências Sociais, [s.l.], v. 27, n. 80, p. $21-36,2012$.

TSING, Anna L. Viver nas ruínas: paisagens multiespécies no antropoceno. Brasília, DF: IEB Mil Folhas, 2019.

UNO, Kuniichi. Hijikata Tatsumi: pensar um corpo esgotado. São Paulo: n-1 Edições, 2018.

VIANNA, Klaus. Dançar o movimento da vida. Lua Nova: Revista de Cultura e Política, [s.l.], v. 1, n. 3, p. 24-29, 1984.

VIVEIROS DE CASTRO, Eduardo. Perspectival anthropology and the method of controlled equivocation. Tipití, [s.l.], v. 2, n. 1, p. 3-22, 2004.

VON DER WEID, Olivia. Visual é só um dos suportes do sonho: práticas e conhecimentos de vidas com cegueira. 2014. 472f. Tese (Doutorado em antropologia cultural) - Programa de Pós-Graduação em Sociologia e Antropologia, Universidade Federal do Rio de Janeiro, Rio de Janeiro, 2014.

VON DER WEID, O. Provincializar a visão: esboços para uma abordagem metodológica. Teoria e Cultura, [s.l.], v. 11, n. 3, p. 131-144, 2017.

VON DER WEID, O. A janela da expressão: reflexões sobre corpo, movimento e gesto nas relações entre visão e cegueira. Anuário Antropológico, [s.l.], v. 44, n. l, p. 159-186, 2019 a.

VON DER WEID, O. On the way: technique, movement and rhythm in the training of guide dogs. Vibrant, [s.l.], v. 16, n. 3, 2019b. 
WINANCE, Myriam. Being normally different? Changes to normalization processes: from alignment to work on the norm. Disability \& Society, october, v. 22, n. 6, p. 625-638, 2007.

\section{Olivia von der Weid}

Professora do Departamento de Antropologia da Universidade Federal Fluminense (UFF, Niterói, Brasil), coordenadora do CONATUS - Laboratório de Pesquisas sobre Corpos, Naturezas e Sentidos. Integra o Comitê Deficiência e Acessibilidade da Associação Brasileira de Antropologia (ABA).

Endereço profissional: Rua Professor Marcos Waldemar de Freitas Reis, s/n, Bloco O, Campus do Gragoatá, São Domingos, Niterói, RJ. CEP: 24210-201.

E-mail: oliviaweid@id.uff.br

ORCID: https://orcid.org/0000-0003-0433-6890

\section{Como referenciar este artigo:}

VON DER WEID, Olivia. Passo a Dois: percepção tátil-cinética na mobilidade com cão-guia. Ilha - Revista de Antropologia, Florianópolis, v. 23, n. 1, p. 127-152, 2021. 